\title{
How to Approach Privacy without Private Sources? Insights from the Franco-Dutch Network of the Eelkens Merchant Family around 16oo
}

\author{
Willem Frijhoff
}

Introduction

Privacy is at the heart of the cultural historians' work, but in most cases, they must construct it from sources not meant or intended to present it. $^{1}$ This exercise requires a strong amount of empathy and a well-considered effort of interpretation, on top of the layers of interpretation, which every historical research implies. The availability of adequate sources and an accurate reflection on notions and theory are therefore equally important in all forms of research on privacy. This is still more the case in early modern history. Contrary to the medieval period, for which sources are most often unique or have been conserved piecemeal, for the early modern era many serial sources are or have been made progressively available, such as baptismal and marriage registers, notarial deeds, lawsuits, alba amicorum, ${ }^{2}$ or private correspondence. Moreover, personal journals, and other so-called ego-documents that have come to the fore in research in the last forty years or so are one of the most obvious sources for research on privacy. They permit a privileged view into many aspects of reconstructed or publicly displayed personal life stories. However, contrary to our current period, relatively few sources permit a direct view into the inner life, the emotional impetus, and the expressed motivations of historical persons. The ambition of the cultural historian is to go beyond the simple facts of life listed in formal documents. They intend to discover, disentangle, and reconstruct meaningfully the experience and agency of the individual in the triple environment of family and kinship, community, and society, and hence to assess the influence of each of these vital dimensions on the subject's life story.

1 All translations are mine unless otherwise stated.

2 An album amicorum is a notebook in which dedications to its owner were collected. Such an album could be signed at the end of one's studies by fellow students or during the Grand Tour (an educational journey). 
This historian's ambition to get a better understanding of the historical character of past societies regards directly the notion of privacy for at least two reasons. Firstly, historical research into what privacy entails permits us to discover the dimension of personal agency as a constituent of an ever more global and general historical analysis. It asks the question of what exactly motivates a person beyond acquired cultural conventions, group constraints, common habits, or instinctive and seemingly self-evident traditions, and how human will, chance, accident, and unplanned circumstances affect the life, thought, and agency of the individual as well as of the community. Secondly, research into privacy always implies the risk of a personal involvement of the historian because privacy as a historical category escapes any general categorisation. Privacy must always be constructed as a subject of history or memory, including in historical sources focused directly on the private dimension of human life. More than other historians, those conducting privacy research must therefore remain particularly aware of their own involvement in their research theme and in the way they construct their argumentation.

Yet, there are levels in the historical analysis of privacy. The first level is that of the construction of the formal distance between an individual and the objective environment in which s/he lives. People do not automatically adopt the structures, conventions, and uses of the society or community in which they have been educated and/or in which they live, but they adapt them and memorise them in accordance with the variety of their experiences and impulses that mark their individual existence in each historical environment. This means that people with a virtually identical background may in fact behave and structure their life in very different private ways, without feeling a substantial gap in the field of their common experiences. This level of objectivated, semi-public privacy is the most easily accessible one for the historian because it can be researched by examining objective or material, often public sources about the data of personal life, writings, work, and social contacts. The second level of privacy is that of the way in which these facts and relations are lived, assimilated, and remembered in the mind of individual persons, and in which they acquire a specific personal meaning and become the starting point of new individual actions and experiences, either consciously or unconsciously. The sources included in this second level are in themselves subject to caution, however, because they do not speak directly or objectively.

For many years, my own research as a cultural historian has focused on the relation between personal agency in the private sphere and social frameworks, networks, and constraints, including both levels. ${ }^{3}$ I deem it important

3 See Frijhoff W., Wegen van Evert Willemsz. Een Hollands weeskind op zoek naar zichzelf, 1607-1647 (Nijmegen: 1995) [English version: Frijhoff W., Fulfilling God's Mission: The Two 
for historians to account publicly for their reconstruction of history and their images of the past, and to explain their personal position in their research fields. In what follows, I will take some elements from my recent ongoing research an extensive micro-historical study of an early modern Franco-Dutch cluster of families - to illustrate my points on early modern notions of privacy. I will focus on the two levels of privacy defined in the previous paragraph and try to discover how they can be combined for the global analysis of privacy in a specific historical cluster of persons. My analysis will be based on the example of the extended Eelkens family from Bois-le-Duc ('s-Hertogenbosch, in the Dutch province of Brabant), heavily engaged in the international fur trade of the time. Although citizens of the Dutch Republic, they remained active members of the Catholic Church, which in a formally Protestant state was a first opportunity for privacy arrangements.

The interest of this family cluster lies in the fact that contrary to the documentary basis of many analyses by cultural historians, its members did not leave a substantial volume of writings that would have made it easy to address their life straightforwardly in terms of spiritual experience. We must discover, define, and finally solve the cluster of their individual actions, expressions, and possessions, and of their spiritual, social, and material culture. We must then recombine them into the privacy dimension of a family story. In fact, this is a challenge. It requires ongoing research in several layers of sources and cannot really be achieved in the context of one scholarly article, where just the general trends of the approach can be presented.

Worlds of Dominie Everardus Bogardus 1607-1647 (Leiden - Boston: 2007)]; idem, Embodied Belief. Ten Essays on Religious Culture in Dutch History (Hilversum: 2002). On the research method, see Frijhoff W., "Experience and Agency at the Crossroads of Culture, Mentality, and Contextualization. The Biography of Everhardus Bogardus (c. 1607-1647)", in Bödeker H.E. (ed.), Biographie schreiben (Göttingen: 2003) 65-105; idem, "The Improbable Biography: Uncommon Sources, a Moving Identity, a Plural Story?", in Berghahn V.R. - Lässig S. (eds.), Biography between Structure and Agency: Central European Lives in International Historiography (Oxford - New York: 2008) 215-233. Other examples are Frijhoff W., "Seitenwege der Autonomie. Wege und Formen der Erziehung in der Frühen Neuzeit”, in Jacobi J. - Le Cam J.L. Madoff H.U. (eds.), Vormoderne Bildungsgänge. Selbst- und Fremdbeschreibungen in der Frühen Neuzeit (Cologne - Weimar - Vienna: 2010) 25-42; idem, "A Misunderstood Calvinist: The Religious Choices of Bastiaen Jansz Krol, New Netherland's First Church Servant", Journal of Early American History 1 (2011) 62-95. The work and approaches of Michel de Certeau have inspired me for many decades: idem, "Michel de Certeau (1925-1986)", in Daileader Ph. - Whalen Ph. (eds.), French Historians 1900-2000. The New Historical Writing in Twentieth-Century France (Chichester: 2010) 77-92. 


\subsection{Jacob Eelkens (1591/92 - in or after 1634)}

Let me start with the figure of Jacob Eelkens - or Jacques, as he commonly called himself, probably because the family identified itself with the French-speaking immigrants in Amsterdam, or perhaps to be distinguished from his homonymous father Jacob senior. The latter, himself a chamois merchant, was born in Bois-le-Duc in 1571 but settled as a fur trader with his family in the heart of Rouen in 1599, at the corner of the central marketplace. In 1610, he founded in Le Havre a company for commerce between France and Canada and he died in Rouen in $1629 .{ }^{4}$ Young Jacob junior was himself an intelligent merchant who owing to his role in the fur trade was one of the first Dutchmen to live among the native Americans in the brand-new colony of New Netherland, the present-day state of New York. He must have decided to settle among them without conserving the links with the family in his fatherland, about which there is no trace in the Dutch archives until his return some years later. He traded with the natives, learned, and spoke their languages, and, as we may infer from his commercial success and the positive image the natives maintained of him until long after his death, he must have adopted their way of life and understood their social intercourse during his prolonged and most probably isolated stay among them in the years 1612-1614. The European traders called the natives 'Wilden' ('Savages' or 'The uncivilised'), but in the eyes of young Jacob they were evidently not without regulated conduct, although the parameters of their norms, values, and actions did not conform to those of the European Christians. He proved to be able to adapt, at least temporarily, his world picture and agency to this new social environment. He developed and adapted his private standards for a fruitful exchange in accordance with what the natives expected from him [Fig. 5.1].

Obviously, the question of the relationship between private norms and public appearance looms large in the research for the life story of such an isolated trader in a very new environment. How did he manage to be accepted? How much of his European values and customs did he give up for integration in such foreign cultures? Did this include the semi-private sexual promiscuity customary between members of befriended tribes, and subsequently quite often also between Europeans and natives? Did he share his life with Indian women and perhaps have children with them? Some time later this was notoriously the

4 Most sources of this article are listed in Frijhoff W., "Jacob Eelkens Revisited: A Young Franco-Dutch Entrepreneur in the New World", De Halve Maen. Magazine of the Dutch Colonial Period in America 88.1 (2015) 3-12. 


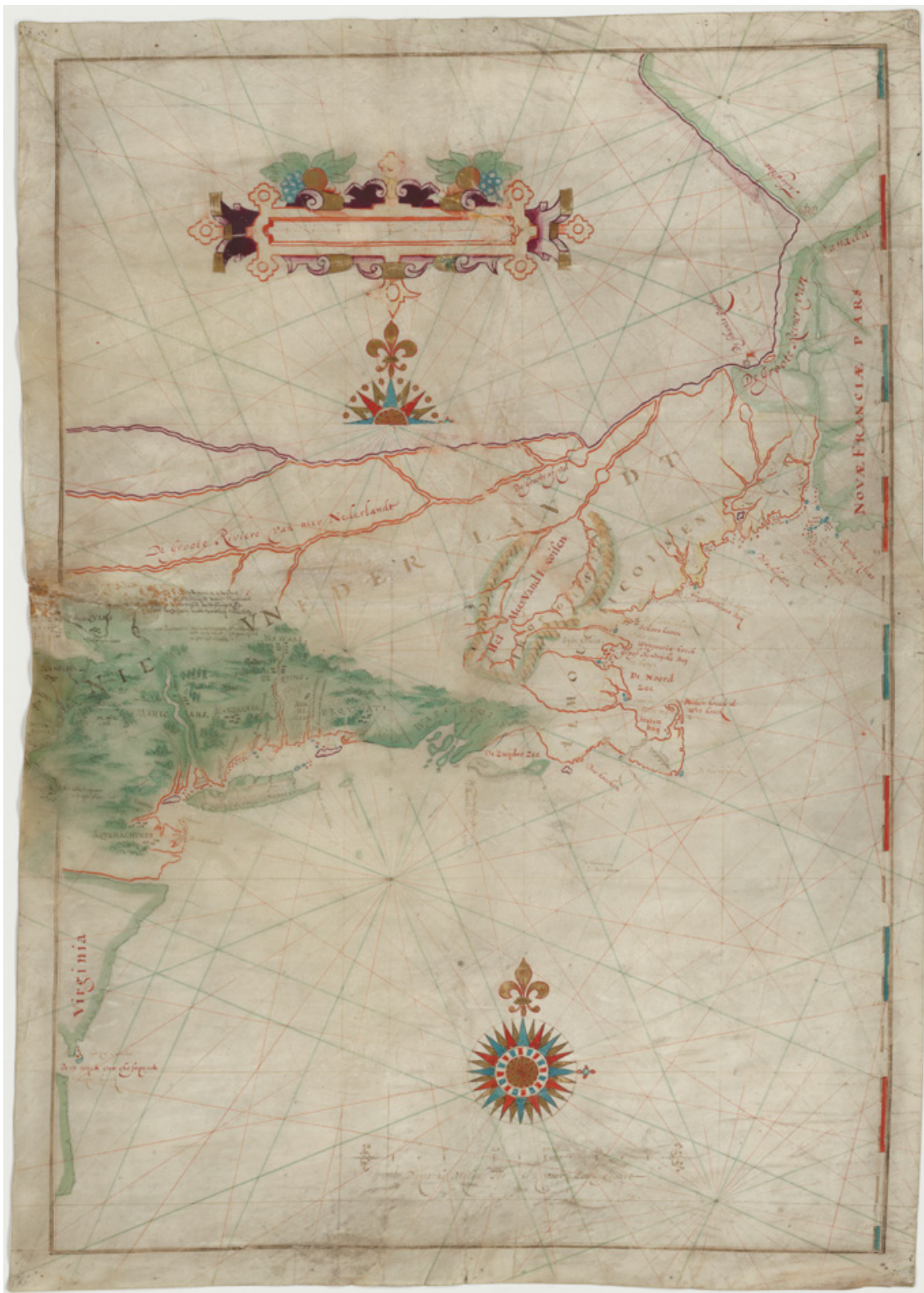

FIGURE 5.1 Adriaen Block, Kaart van Nieuw-Nederland, benevens een gedeelte van Nova Francia en Virginia (The first map of New Netherland [now New York State], between Virginia and New France), 1614. Map, $0.64 \times 0.49 \mathrm{~cm}$. To the left in the middle: the Hudson river and the meeting site of the native nations. Jacob Eelkens probably used this map (or a lost copy of it) during his three-year stay among the natives. The National Archives, The Hague, 4.VEL Inventaris van de verzameling buitenlandse kaarten Leupe, 1584-1865, 520

(C) THE NATIONAL ARCHIVES, THE HAGUE 
case with several other colonists, whose European-Indian children born out of wedlock played a role as interpreters and go-betweens among the ethnic groups, and were even baptised in some cases, although the natives generally remained very reluctant towards European, Christian rituals. At that time Jacob was not yet married and nothing specific is known about any American offspring. During his short stay in Amsterdam in 1619, he married a carpenter's daughter, Grietgen Wolferts (he was 27 and she was 29), but nothing is known about their children either.

However, in 1643, thirty years after Jacob's first stay in North America, a group of Indian chiefs traded with the Dutch merchant David Pietersz de Vries (15931655), known among them as a friendly and trustworthy trader, just like Jacob Eelkens, who by then had disappeared from their view. In the autobiographical book De Vries published later, he quoted extensively the speech held at that meeting by an Indian chief who complained about the bad treatment inflicted upon his people by the Europeans. ${ }^{5}$ The chief told how upon the arrival of the first European ships, one generation earlier, the Indians had guarded and sold the ship's load for them, protected the sailors as 'the apple of their eye', and lent them their daughters to sleep with. The chief also claimed that they had had children with them - many natives, said he, were the fruit of a union with a European. Therefore, when Europeans fought and killed natives, they killed their own blood. The chief must have referred here to, among others, Jacob Eelkens, who was one of the leaders of the first expeditions and who was probably the only one that remained settled among the natives during extensive periods. Implicitly, the chief's speech teaches us also that the notion of privacy, if ever it existed, must have had a different meaning among the natives than among the Europeans when it came to intimate relationships for unmarried couples, which formally would be disallowed by Christian teachings.

We know, at any rate, that, together with his ship's captain Hendrick Christiaensz (who died in 1619 during an Algonquian attack), merchant Jacob Eelkens was also the first European to conclude, early in 1613, a formal treaty of commerce and friendship with the native tribes to secure the fur trade. According to local lore, a covenant chain and a wampum band with two rows of shells, one for each of the partners, sealed the treaty. The agreement permitted the 1614 construction of the first European fortress in that area at the site on the Hudson River where the Iroquois and Algonquin tribes had their meeting-place, near present-day Albany. It was called Fort Nassau. Jacob

5 Vries David Pietersz de, Korte Historiael ende Journaels aenteyckeninge van verscheyden Voyagiens in de vier deelen des Wereldts-Ronde, 4 vols. (Hoorn, voor D.P. de Vries: 1655), ed. H.T. Colenbrander (The Hague: 1911). 
became commander of that small fortress and would stay there as a merchant for some time. The treaty included the so-called Five Nations, i.e., the Mohawks of the Iroquois confederation on one side of the Hudson, but also their rivals, the Mahicans on the other side. This two-sided covenant was essential for securing peaceful commerce because, contrary to the rather peaceful Mahicans, who were devoted to agriculture, the Iroquois were a belligerent nation. The Iroquois tribes cultivated a rather aggressive attitude towards any competitor and they were known for a culture of refined cruelty towards their rivals. As such, they must have appreciated Jacob's own strong and outspoken personality that reflected their own bravery. In their negotiations with the white colonists at the end of the seventeenth century, three generations later, the Iroquois tribes kept a vivid remembrance of 'a governor called Jacques', the prototype of a good European in terms of conviviality, friendship, and accommodation with the natives, who should be an example for their white neighbours. ${ }^{6}$

Yet, in subsequent years, Jacob engaged in less friendly actions. In 1622, as commander of Fort Orange, the successor of Fort Nassau, he was responsible for the capture of a sachem (chief) of the Sequin or the Pequot tribe. He released the chief after ransom was paid in sewant or wampum, money consisting of shells on a string. But after due reception of the money, the chief was killed nonetheless - proof that the Europeans could not be trusted, as the Dutch chronicler Nicolaes van Wassenaer judged the treacherous behaviour of Jacob himself or his companions some time later. ${ }^{7}$ This public crime made the natives seek vengeance and resulted in years of fear and misery among the immigrants who colonised the Indian territories. In his later life Jacob fought several battles with the Dutch authorities as well as with some Indian tribes, and he probably died in or after 1634, in the service of the English fighting the Dutch in America. ${ }^{8}$ There is in this case an obvious dissonance between the European and the Indian norms of privacy in what concerns sexuality. The trusting relationship Eelkens establishes with the natives at first enables him

6 Richter D.K., "Rediscovered Links in the Covenant Chain: Previously Unpublished Transcripts of New York Indian Treaty Minutes, 1677-1691", Proceedings of the American Antiquarian Society $92.1(1982) 45^{-85}$, here 48-49, 75-76, and 81.

7 Wassenaer Nicolaes van, Historisch verhael alder ghedenck-weerdichste geschiedenisse, die hier en van den beginne des jaers 1621 [tot Octobri des jaers 1632] voorgevallen syn, vol. 4 (Amsterdam, n.p.: 1626) November 1626.

8 De Vries, Korte Historiael (ed. 1911) 174-175; Winthrop John, A Journal of the Transactions and Occurrences in the Settlement of Massachusetts from the year 1630 to 1644 (Hartford, Elisha Babcock: 179o) 48; O'Callaghan E.B., Documents Relative to the Colonial History of the State of New York, vol. 1 (Albany: 1853) 71-81, 91-95. 
to enter their 'private' comfort zone and achieve a favourable trade agreement, but does not prevent him from betraying their trust when it is convenient for him.

\subsection{François Eelkens (1595-1665)}

Genealogical research has revealed that Jacob (Jacques) Eelkens was the elder brother of another intriguing personality, François Eelkens, one of the very first members of the new Tridentine congregation of priests called the Oratory of Jesus. ${ }^{9}$ Full of zeal for the conversion of the Protestants and the reCatholicisation of his Dutch fatherland, he worked in the clandestine Catholic Holland Mission in Leiden, where in the years 1640-1643 he was also the confessor of the army officer and philosopher René Descartes (1596-1650), who, although living his public life in a Protestant state, had conserved his private convictions and rituals as a practising Catholic. ${ }^{10}$ Contrary to the ambiguous reputation of Jacob Eelkens as a good European on the one hand, and easily breaking his word on the other hand, his younger brother François won the fame of a living saint' as director of his religious community in Brussels. Such intriguing coincidences of exceptionally active lifestyles of seemingly opposite personalities justify the search for public or private elements in their life stories that could explain their diverging life courses and spiritual orientations. Jacob and François were brothers, but did not have the same legal status. Jacob, born before the marriage of his parents, was an illegitimate child and as such could not play any part in his family's legal proceedings nor legally inherit its fortune. Due to this impediment, he lived virtually outside the public sphere of his parents' life. His grandmother left him some money in her will, undoubtedly aware of young Jacob's fragile future, but nothing is known about a possible donation by his parents. Besides, although Jacob worked for some years as a merchant in the corporation of his uncle Hendrick Eelkens (1575163o) who was trading with North America, he remains totally absent from all those family records in which common family concerns are settled and the family members sign their agreement. I assume that his seclusion, typical of the legal status of illegitimate children, must have been the trigger for his need to develop a private life course far from his family's public life and from any major intervention of its members.

$9 \quad$ Frijhoff W., "The Oratory in the Seventeenth-Century Low Countries", Revue d'histoire ecclésiastique 107 (2012) 166-222, here 196.

10 Cf. Baillet Adrien, Vie de M. Descartes, 2 vols. (Paris: 2012 [Paris, chez Daniel Horthemels: 1691]). See vol.1, 194; vol. 2, 527 . 
Jacob's younger brother François did not inherit from his family's fortune either, but for a very different reason. He was a priest and he belonged to a religious congregation that, according to custom, would have seized and used for its own exclusive profit whatever heritage he would have received. From the very start the two boys followed their own path. François's priestly status corresponded well with the family's religious outlook and ambitions. As helper of the victims of the plague in France in the 1620s, as director of the Oratorian college in Louvain, as superior of the noviciate in Brussels, and as an investor in the 1656-166o land reclamation project on the island of Nordstrand (Holstein) set up by members of his congregation, he figures in several documents regulating the status, the morality, and the future of its members. ${ }^{11}$ Yet, his personal life story shows a man gifted with a very strong will, open to whatever life might bring him - an openness and a receptive mind similar to what we have just seen of his older brother.

\subsection{Two Brothers in Public and in Private}

To understand the relations between these two private lives, their common family background, and their public representation, at level one, I have reconstructed the entire family, including some generations of the brothers' paternal and maternal ancestors, to discover until what point something like a family habitus, transmitted by education, could be defined, and where personal choices interfered. Next to material factors such as the transmission of money, housing, or an enterprise, and the concern for a suitable education and a marriage with an appropriate partner, family habitus is also a private factor, or at least a factor privately transferred and difficult to retrieve or define in the sources. But in societies with a rather stable social hierarchy like those of early modern Western Europe, family habitus explains much of the good (and occasionally the bad) fortune of a family over time, from generation to generation. In this research, I discovered how tightly the extended Eelkens family and its many members were entangled in a complex kinship of five or six families in Amsterdam and Rouen, closely interrelated by marriage, work, cultural level, social status, and religious choice. This kinship was expressed and duly appreciated in a multiplicity of actions, texts, formulas, situations, and relations, clearly showing that the members of these families shared a common interest and common work for common targets in their public life. They did so

11 Heussen Hugo Franciscus van, Historia Episcopatuum Foederati Belgii, vol. 1 (Leiden, Christiaan Vermey: 1719) 431; [Swert Pierre de], Archi-Episcopatus Mechliniensis diffusae (Whitefish, MT: 2010 [Lille, Petrus Matthon: 1740]) 35-36, 73, 81, 85, and 102-103. 
in two different areas: professionally, as international merchants, and privately, as practising Catholics who tried to save their faith and re-Catholicise their country in the context of the clandestine exercise of their religion to which they had been forced by the Reformed authorities of the Dutch Republic.

The Eelkens family comes from Bois-le-Duc, in Brabant, where they can be traced back to the early fourteenth century, when they participated in the leather crafts or the fur trade. My reconstruction focuses more specifically on the migration of enterprising family members to the commercial metropolises Amsterdam (Holland) and Rouen (Normandy, France) between 1580 and 16oo, of their offspring to Cologne (Holy Roman Empire) and Oslo (Denmark-Norway) in the decades around 16oo, and later to Antwerp, Brussels, and Paris. However, this work constantly provokes new questions of a theoretical and methodical nature, such as whether we can imagine and reconstruct what privacy means in an early modern metropolis of tens of thousands of inhabitants, surrounded by city walls, and crowded far beyond the point of reasonable human population [Figs. 5.2-5.3].

By 160o-1625, both Amsterdam and Rouen were crowded, growing cities of probably 60,000 to 80,000 inhabitants, obviously lacking private space. ${ }^{12}$ Amsterdam even tripled that number over the century, arriving at more than 220,000 inhabitants. Around 16oo, before the great expansion of Amsterdam with the famous circular range of canals, it was nearly impossible to secure intimacy outside the most basic needs. Just like the less affluent burghers, the mighty regents and the richest merchants lived in high and narrow houses in equally narrow commercial streets, like the main artery, the Warmoesstraat at present the centre of the drugs and sex trade of the city. Persons of different family backgrounds or origins often shared bedrooms and even beds, as I have been able to show in my study on the youth of the Reformed minister Everardus Bogardus (16o7-1647), who shared his bed with several children in the orphanage of his small town of Woerden. Hence, they noticed each other's dreams and consequently interacted, as well as exposed these dreams to the authorities when asked. ${ }^{13}$

12 Frijhoff W. - Prak M. (eds.), Geschiedenis van Amsterdam, vol. 2-1: Centrum van de wereld 1578-1650, 2nd ed. (Amsterdam: 2009 [2004]); Farin François, Histoire de la ville de Rouen, 3 rd ed. (Rouen, chez Louis du Souillet: 1731).

13 Frijhoff W., Fulfilling God's Mission 64-65. Young Bogardus's dreams revolved around religious topics and his own spiritual vocation. 


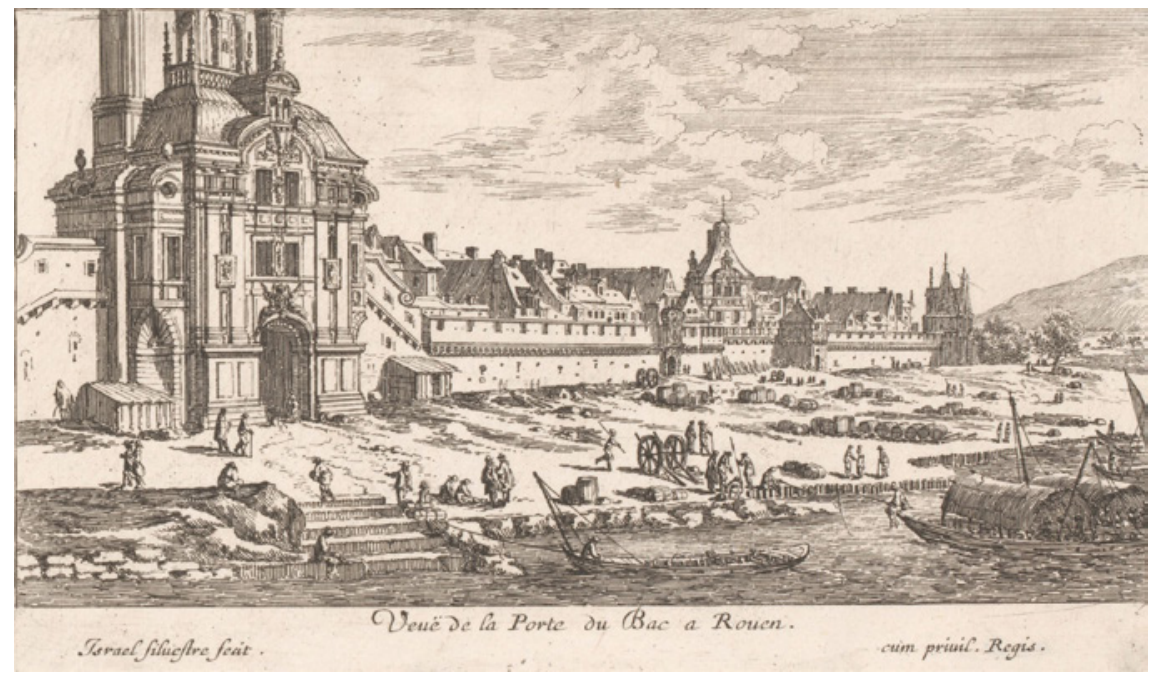

FIGURE 5.2 Israël Silvestre, Gezicht op de haven van Rouen (View of the Harbour of Rouen), ca. 1657 . Print, $11.8 \times 20 \mathrm{~cm}$. Le Port du Bac was located close to the trading district. (C) RIJKSMUSEUM AMSTERDAM

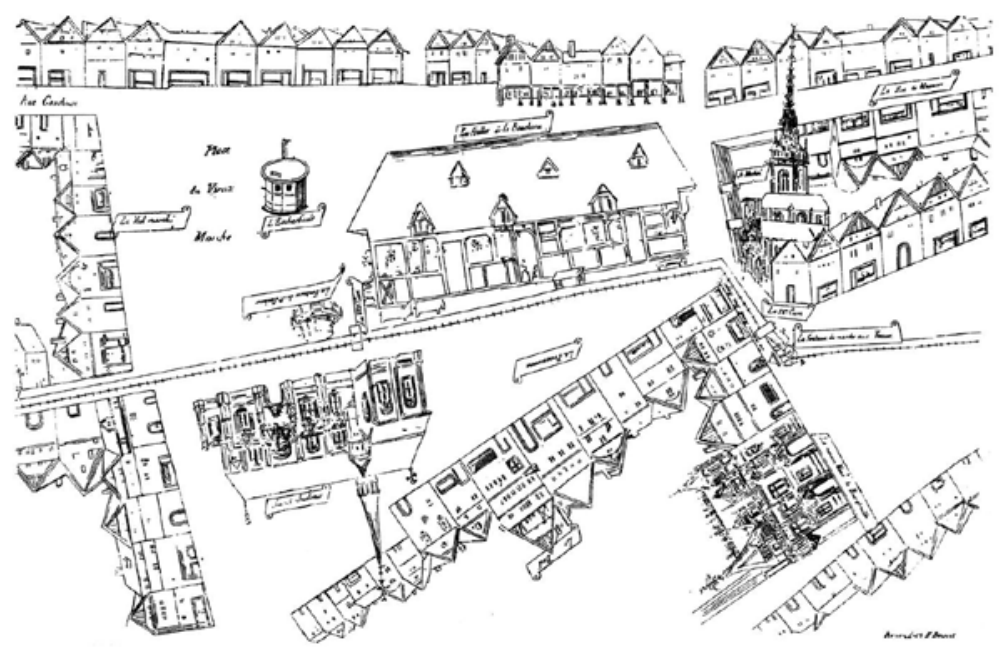

FIGURE 5.3 Helen M. James - Jane E. Cook (illustr.), Plan of the Vieux-Marché and of the Marché aux Veaux, 1899. Print. Rouen, the Old Market Place after an early sixteenth-century town map, showing the Butchers Hall and two parish churches, St. Savior and St. Michael (on the right). Next to St. Michael, the Eelkens lived at the angle of the rue du Massacre or the rue du Gros-Horloge, north of the church where Jacques and Pierre Eelkens were treasurers. From: Cook Th.A., The Story of Rouen (London: 1899) 209

(C) PROJECT GUTENBERG 


\section{$2.4 \quad$ The Local Setting}

The same density in population marked early modern Amsterdam. This is clearly shown by one particularly rich source, the registers of the 1606 lottery organised throughout the province of Holland for the construction of a charitable institution in Haarlem. ${ }^{14}$ Thousands of inhabitants of Amsterdam participated in the lottery: young and old, male and female, masters and servants, who all adored gaming and wagering, as most Dutch people did at that time. Next to a personal rime or a short textual identification, the registers list the address and the name of the proprietor or main tenant. On close analysis, it appears that next to the family with its children and sometimes their grandparents, a sizeable number of servants, co-workers, tenants, lodgers, and other people who did not belong to the nuclear family often shared the family home. Moreover, much space was taken by the warehouse function of all merchant dwellings in the early modern cities before they were extended beyond the old city walls. Finally, the spatial division between work and family life was not self-evident until later in that period [Fig. 5.4].

The probate inventories of the properties, monetary assets, and material possessions of deceased family members constitute another precious source. Sworn women, who were able to identify and describe less common and even rare objects, described room by room the content, furniture, objects, garments, and paintings in the houses of the deceased. The notarial registers indicate overcrowded interiors shared by many co-residents and rooms with a plurality of functions, in which individuals, men and women alike, most often had to conquer space for their private sphere and personal needs. The beautiful images of clean, seventeenth-century Dutch interiors with expensive furniture but nearly void of inhabitants, portrayed by painters like Johannes Vermeer (1632-1675), Nicolaes Maes (1634-1693), or Pieter de Hooch (1629-1684), in fact hardly depict reality. They are emblematic constructions of the theme of 'domestic intimacy' that suited the new ideals of familial privacy of the successful bourgeoisie and the upper layers of society. ${ }^{15}$

14 See for example: "Registers Haarlemse Loterij 1606 - nrs. 2-3". Online edition. Accessed 1 April 2021. https://www.vpnd.nl/bronnen/nh/haarlem_loterij16o6/haarlem _lot16o6_o1.pdf/. Such registers of the so-called 'Haarlem's Lottery' existed also for other Dutch cities, including Amsterdam, Delft, Gorcum, and The Hague.

15 One study presenting such new ideals is Stevin Simon, De Huysbou. See the edition by Van den Heuvel Ch., 'De Huysbou': A Reconstruction of an Unfinished Treatise on Architecture, Town Planning and Civil Engineering by Simon Stevin (Amsterdam: 2005). 


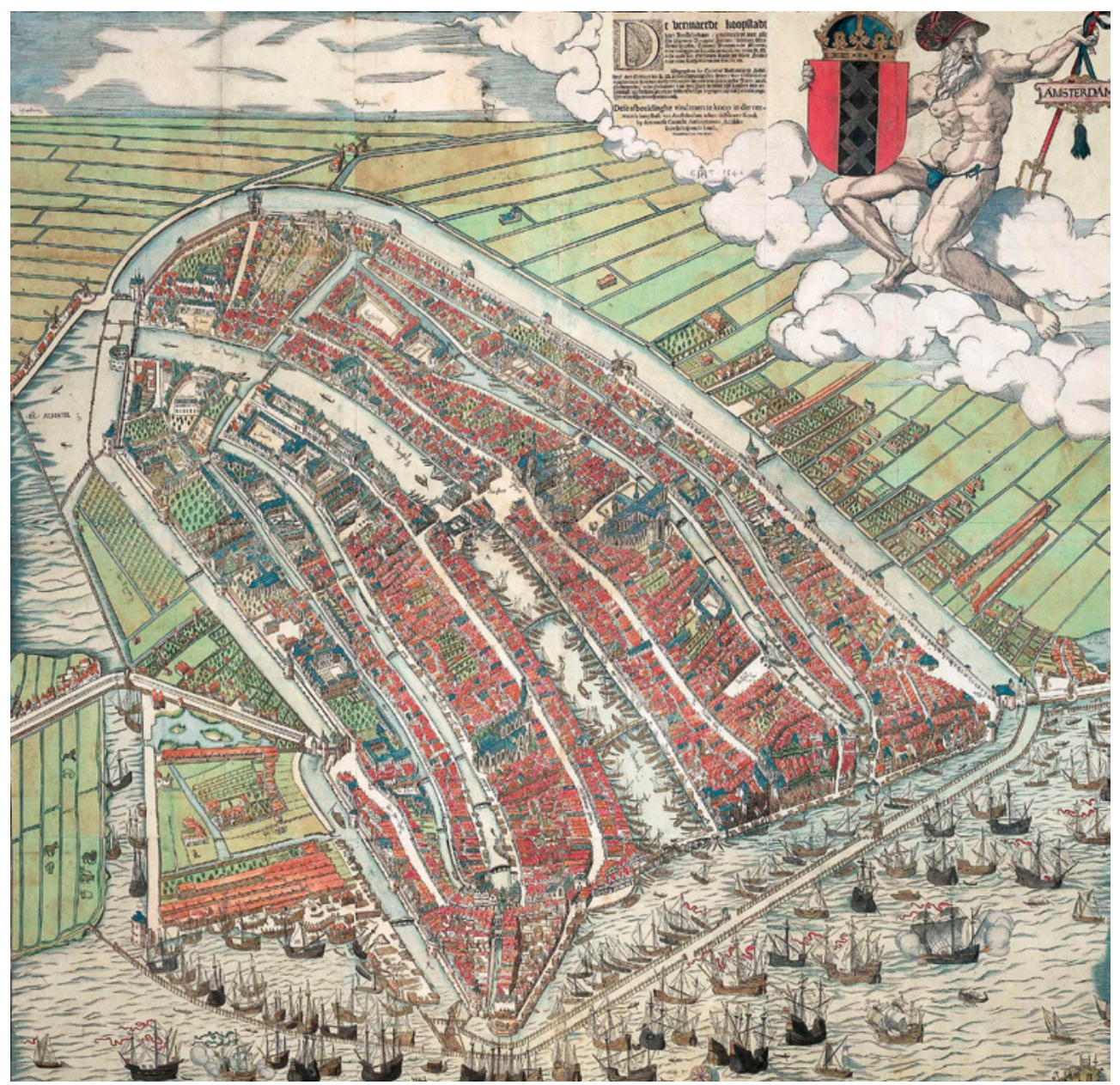

FIGURE 5.4 Cornelis Anthonisz, Bird's eye view of Amsterdam, 1544 [reprint published by Ian Iansz. 1557]. Print, $10.7 \times 10.9 \mathrm{~cm}$

PUBLIC DOMAIN. WIKIMEDIA COMMONS

\subsection{When Private Turns Public: The Case of Swaentgen Joosten (1579)}

The families I am dealing with counted many illegitimate children, 'bastards' who had to construct their own, personal way of life, often diverging from the prevailing habits of their family. Half-brothers and half-sisters were common in the repeated stream of remarriages due to frequent deaths in childbirth and deaths from the plague and other diseases without a proper diagnosis or treatment. They could put the family cohesion under pressure or even cause splits. Take, for example, the family of Swaentgen van Dulmen (1569-1652), the mother of Jacob and François Eelkens. She was the daughter of the wholesale 
merchant in herbs and spices (a grocer, in the terms of that day) and pharmacist Court Jansz van Dulmen (1538/39-16o2). He had migrated to Amsterdam from the small Westphalian town of Dülmen, close to the Dutch border, and established his flourishing shop, in fact a small proto-industrial and semi-colonial enterprise, at the corner of the Warmoesstraat and the Dam Square, in the very centre of the city. Court himself was a son of Johann Courdes (ca. 150oafter 1540), one of Dülmen's burgomasters (city magistrates) and probably the grandson of a schoolmaster. Court may have inherited his grandfather's interest in knowledge that he manifested in his donation to Leiden University Library as early as 1597, of a Javanese manuscript on the Mahometan religion brought by his correspondents from their voyage to the isle of Java. ${ }^{16}$ Johann Courdes had children from what seems to have been a rapid series of three marriages. They mostly called themselves 'van Dulmen' after their town of origin, or used a patronymic like Jansz, son of Jan, a paternal reference that favoured the links of family intimacy. Johann Courdes's close family included a stepson from a previous marriage of one of his spouses, Michiel (born probably before ${ }_{1538}$ died 1607/o8), who also called himself Fonteyn. In later years, Michiel Fonteyn migrated to Oslo in Norway where he married and rose to some local fame as a merchant and magistrate. But first all these relatives migrated to Amsterdam in the 1560s and formed a tight clan of immigrants there, acting in close union on many occasions during several decades. Apparently, the individual fate of these family members was largely determined by the family habitus, a preexisting frame of family interests, modelled after the common image of the family's public trajectory as traders in different goods, such as groceries (spices from other continents), beer, or timber, always with a view to the overseas trade [Fig. 5.5].

Yet, these bonds could be too close, even suffocating, for those who claimed a personal choice for their future and wanted to escape the compelling family habitus. That was the case of Swaentgen Joosten (before 156o-1607), a niece of Court Jansz van Dulmen, daughter of his half-brother Joost Jansz (ca. 15351588?). In 1579, she lived in the home of her uncle Court, in the grocery shop near the City Hall of Amsterdam when she wanted to marry young Wouter Willemsz (ca. 1555?-1612), the son of Willem Corsz (who had died in 1572/73). Wouter was an up-and-coming timber merchant who some years later had a popular inn and an auction house in the Zeedijk, the neighbourhood where

16 Leiden University Library, Oriental Ms. 266. On its origin: ibidem, Ms. BPL 747, "Letter from Paullus Merula to Conradus van Dulmen", ibidem, October 1597; Molhuysen P.C., Geschiedenis der Universiteits-Bibliotheek te Leiden (Leiden: 1905) 18, footnote 1. 


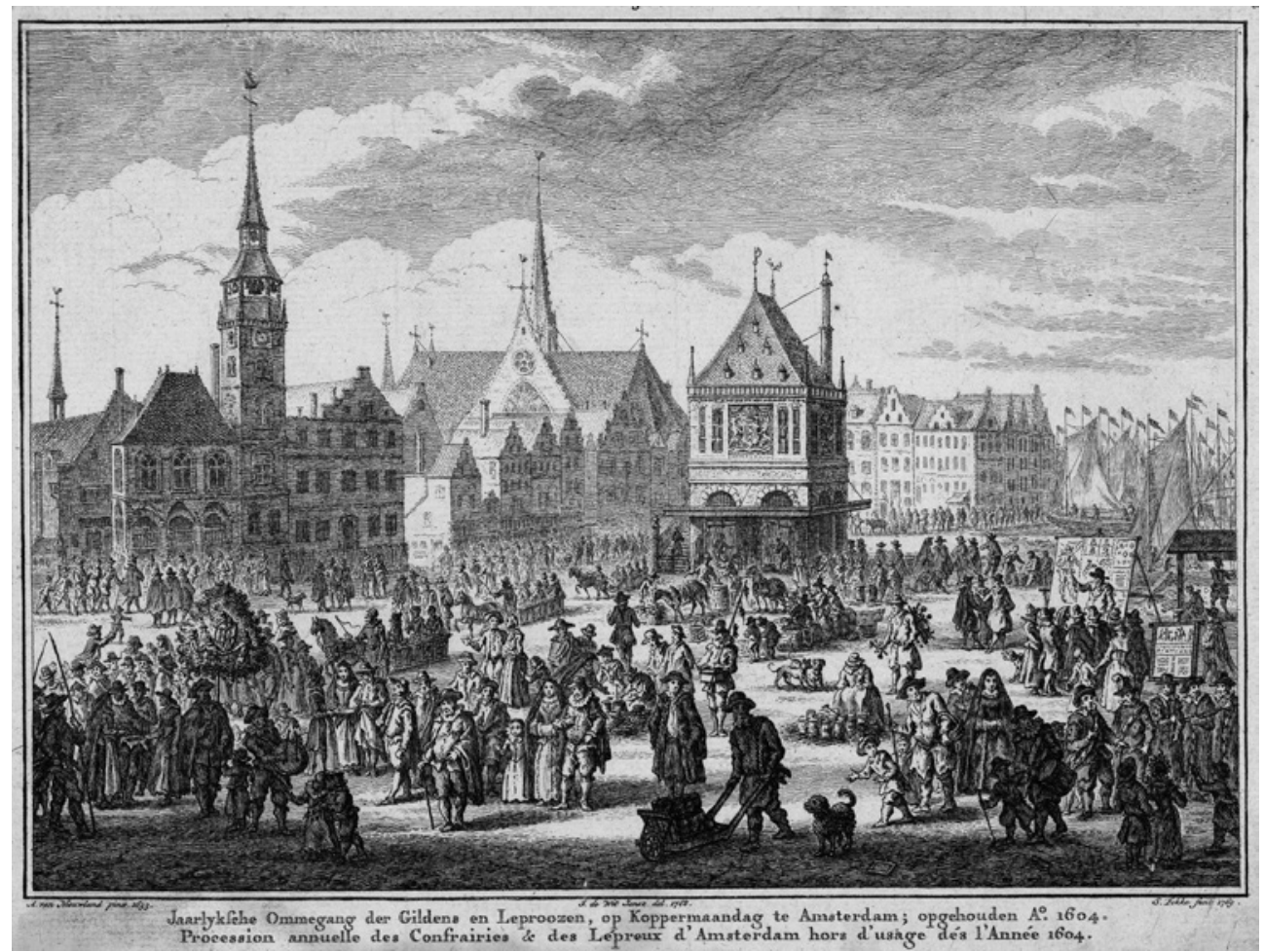

FIGURE 5.5 Simon Fokke, after Izaak Jansz. de Wit, after Adriaen van Nieulandt, Koppermaandag met leprozenoptocht te Amsterdam, 1604 (Plough Monday with Leper Parade in Amsterdam, 1604), 1769. Print, $19 \times 25.5 \mathrm{~cm}$

(C) RiJKSMUSEUM AMSTERDAM

the sailors spent their modest wages on drinks. ${ }^{17}$ When Swaentgen's uncle Court, who acted as her legal guardian, refused to agree with her choice, she left his house against his will and went to her sweetheart with whom she 'oock alsoo dat sy enige dagen by malcander gegeten, gedroncken, geslapen, ende als getroude luyden geleeft hadden' ('lived, ate, drank, and slept as a married couple during several days'), as the commissioners of marital affairs formally stated. ${ }^{18}$ That must have been quite a public scandal. Having lived as husband and wife, as the terms of the formula proved, they claimed the right to be known as a married couple. However, the commissioners refused to accommodate this demand and urged for a reconciliation with her uncle. In vain. When

\footnotetext{
17 Hell M., De Amsterdamse herberg 1450-1800. Geestrijk centrum van het openbare leven (Nijmegen: 2017) $15^{2}$.

18 Municipal Archives Amsterdam, DT в 762, fol. 8 (4 July 1579).
} 


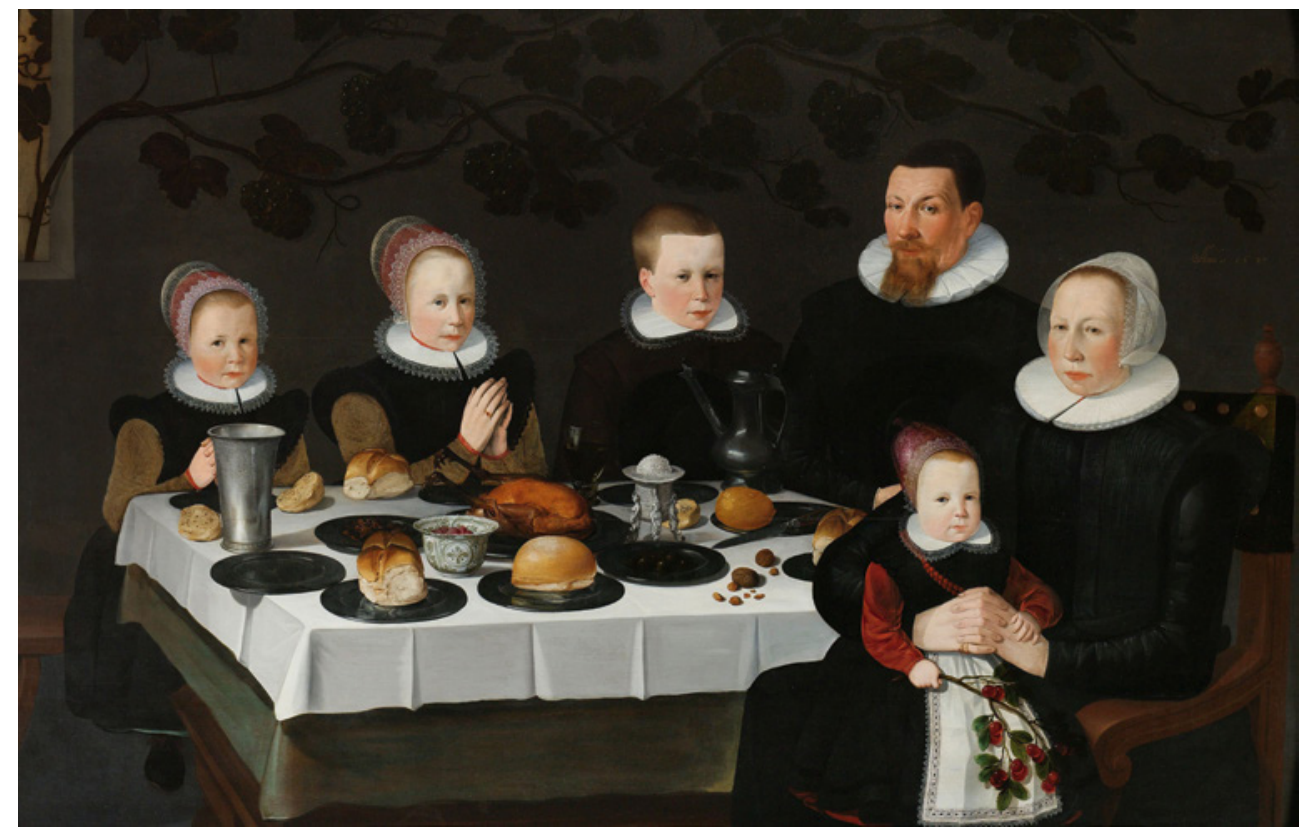

FIGU RE 5.6 Anonymous, Welvarende calvinistische familie (Prosperous Calvinist [?] Family), 1627. Oil on panel, $22 \times 19.1 \mathrm{~cm}$

(C) RIJKSMUSEUM AMSTERDAM

the young man persisted in his marriage design, his family brought the affair before the burgomasters. The burgomasters summoned all those involved to the city hall together, and after ample consultation they concluded that the matter had gone too far. While the initial relationship of the couple was private, i.e., involving just the two of them, it had become known to their close relatives and probably also their extended family. At the third stage, when the scandal was brought to the attention of the magistrates, it became truly public. As at this point it would have been known to all, the burgomasters decided that their prolonged near-public concubinage justified a formal marriage with a consummation in facie ecclesiae (in the face of the Church). Guardian Court van Dulmen remained opposed to this solution, but once the marriage was formally concluded, the burgomasters achieved his reconciliation with his niece [Fig. 5.6]. ${ }^{19}$

Swaentgen Joosten may already have been visibly pregnant because her oldest son was born some months later. What seems in this document to have been a purely private affair, involving only the couple and their families, may

19 Ibidem. 
however have entailed a broader background of private choices in a public setting. Indeed, the burgomasters passed judgement on this affair on 4 July 1579, that is, thirteen months after the Alteration - the deposition of the Catholic city government and its replacement by a predominantly Reformed council. ${ }^{20}$ It appears that the younger children of Swaentgen and Wouter Willemsz were baptised in the Reformed Church, and in later years married there. Court van Dulmen, however, remained a convinced and active Catholic, just like his two daughters: the oldest, also called Swaentgen, married to Jacob Eelkens the elder (the father of Jacob and François mentioned above); the youngest, Lysbeth (1571-1640), living in concubinage with the Catholic merchant Hendrick Buyck (1551-1613), who was unhappily married and lived separated from his stern Anabaptist wife. Nevertheless, blood ties proved to be stronger. When 14 years later, in May 1593, Wouter Willemsz and Swaentgen, now prosperous inn owners, drew up their will in their own home, uncle Court was present and granted his permission as Swaentgen's guardian, together with Wouter's Protestant mother. The merchants Hendrick Buyck and Jacob Eelkens, each of them living with one of Court's daughters, and active Catholics too, signed the document as witnesses. ${ }^{21}$ This shows that the family bond, ruptured by the 'private' relationship of Swaentgen with Wouter Willemsz, was restored. Apparently, family ties in the private sphere were more important than public religious dissent.

\section{3}

\section{Level II: Privacy at the Interspace between Public Display and Intimacy}

\subsection{Privacy and Religion}

At this point, I must make some more general remarks. Most members of the families under consideration, in particular the next-of-kin of the Eelkens, showed a militant Catholic spirit in the largely Protestant environment of the Netherlands or in the stern Counter-Reformation atmosphere of early seventeenth-century urban France. Religious identity played a significant role in their identity policy, notwithstanding obvious strategies of religious accommodation and practices of toleration in the public everyday life of that multi-confessional society. ${ }^{22}$ The same holds for their educational strategy,

20 The so-called Alteration (Alteratie) of the city government banning from urban life all public expressions of Catholicism occurred on 26 May 1578.

21 Municipal Archives Amsterdam, Notarial Archives, vol. 22, fol. 108 (notary Jacob Gijsberti).

22 Cf. Frijhoff W., "Dimensions de la coexistence confessionnelle", in Berkvens-Stevelinck C. - Israel J. - Posthumus Meyjes G.H.M. (eds.), The Emergence of Tolerance in the Dutch Republic (Leiden - New York - Cologne: 1997) 213-237; idem "La coexistence 
entailing for some of them a prolonged stay at the Catholic universities of Louvain and Cologne, outside the Dutch Republic. However, most family members were much more doers and go-getters than thinkers or intellectuals. If (international) commerce evidently determined their public fate, how about privacy? To what extent was privacy for them a social matter, regulated by community norms, prescriptions, or unwritten rules in the Catholic community, as an alternative society, obliged to exercise their religion in secret?

An interesting insight into the strength of those norms is a notarial declaration made by a priest still residing privately in Amsterdam in 1596, eighteen years after the Alteration. The declaration was drafted on demand of the widow of Master Maarten Blocklandt, a neighbour in the Warmoesstraat and pensionary (the juridical advisor of the city council of Amsterdam during the Catholic period, from 1564 to 1578 ) and in the presence of two other priests living clandestinely as burghers in the city. The notary was also known as an active Catholic. Viewed in the light of our interest in privacy, the declaration is exceptional because it implies revealing the secret of the Holy Confession that has always been the best guarded of all forms of private communication in the Catholic Church. Blocklandt was accused of connivance with the King of Spain by the Reformed city council of his birth town Amersfoort. The priest who acted as his confessor for fifteen years declared that Blocklandt had never done so in Amsterdam or elsewhere. On the contrary, when he was dismissed from his municipal charge at the Alteration of Amsterdam, he completely retired from public office and turned to a purely private exercise of his profession as lawyer. In his confessions, Blocklandt had never accused himself of any action against his conscience, against the obedience of the Holy Church, or against the King of Spain, not even when the priest had administered the last sacraments on his deathbed. The confessor knew him as a very scrupulous man who certainly would have accused himself of such sins if he had committed them. ${ }^{23}$

For the experienced historian of early modern societies, other, more general but no less seminal, questions also arise during such research. We must avoid projecting modern categories onto historical material and remain close to the sources in a to-and-fro movement between the text and scenarios provided by our sources and our own story, images, or reconstructions. We must therefore always check in which setting and at which level privacy is implied, invoked, or

confessionnelle dans les Provinces-Unies: un régime de connivence à plusieurs vitesses", in Dumont M. (ed.), Coexistences confessionnelles en Europe à l'époque moderne. Théories et pratiques, $X V I^{e}-X V I I^{e}$ siècles (Paris: 2016) 105-124.

23 Municipal Archives Amsterdam, Notarial Archives, vol. 32, fols. 39ov-391r (notary Jacob Gijsberti). 
identified: the familial level, the social level, the inter-confessional level, etc. We must also determine whether we are speaking about historical experience or present-day images of history. One of those tricky master-images is that of the 'tolerant society', cherished by most Dutch people and foreign observers as the privileged image of their Golden Age. ${ }^{24}$ Public toleration would have fostered the rise of individualism and the forms of privacy connected with that image. The main question therefore is whether privacy, defined as the intimate facet of private or public norms and behaviour, really mattered in that society and for the family in its more global activities. Do we, as historians, need the concept of privacy for a global family search? Do the main lines of development, organisation, and evolution not suffice for the historian who wants to obtain an image of a family history in its social setting? Does a search for privacy add anything substantial? At any rate, we must consider the slowly changing relation between the private and the public sphere, a paradigm closely related to the changing perception of the 'self' in history. Therefore, the historian must remain receptive to the changing perception of a fully-fledged sense of individuality in the population of a given historical place and period, or in some of the groups or communities that are part of it.

Applying this demand to the Catholic population of the Dutch cities after the introduction of the Reformation, one of the specific dimensions of privacy in such a secluded community is the need to develop cultural strategies for the construction of the private and the public space within the community itself, that is, in a certain sense, of specific forms of privacy within the generally privatised space of the forbidden religion. There are certainly ways to detect this, for instance via the content of personal libraries, or, still better, in probate post-mortem inventories. The latter show how spaces are arranged within the standard seventeenth-century layout of a private house and how objects are reserved for a still more private confessional use. An example in my research are the documents drafted after the death of Lysbeth Courten van Dulmen in 1640. Her probate inventory states expressly that the portraits of her ancestors and of her second partner (her husband, after a first union without marriage) hung in the public sphere in the front rooms of the house, where well-known social relations could safely be shown. They pertained to the semi-private dimension of her personal identity. But the same was true for the images of

24 Frijhoff W., "La tolérance sans édit: la situation dans les Provinces-Unies", in Delumeau J. (ed.), L'Acceptation de l'autre de l'Édit de Nantes à nos jours (Paris: 2000) 86-107, 127-128, and 131-134; idem, "Religious Toleration in the United Provinces. From 'Case' to 'Model', in Po-Chia-Hsia R. - Nierop H. van (eds.), Calvinism and Religious Toleration in the Dutch Golden Age (Cambridge: 2002) 27-52. 
her former sweetheart outside marriage, his relatives, and their deceased son. However, the portraits of befriended priests and of archduchess Isabella Clara Eugenia (1566-1633), the Catholic sovereign of the Southern Netherlands, who was the enemy of the state but for Lysbeth still must have been the legitimate sovereign, hung in her bedroom. They testified to the permanence of her choice of a more profound private identity, including different values and convictions, and to the desire for another way of life, against the laws of the province. ${ }^{25}$ In his private space, François Eelkens himself cherished the devotion to the child Jesus, a practice that would become seminal for the new spirituality of the Counter-Reformation. He held his everyday private meditations in front of a human-size Jesus figure of coloured plaster in the centre of his bedroom [Figs. 5.7-5.8].26

Privacy emerges in this religious context in two ways. On the one hand, as the private dimension of the public life of the persons concerned and of public life in general; on the other hand, more particularly, as the secret and clandestine form that Catholics had to adopt in Holland in that period. This was so for the Catholics who had remained in Amsterdam, whereas the family members established in Rouen could actively practise their religion. They did so as witnesses at Catholic baptisms, as guardians of Catholic children, and as churchwardens or treasurers of their parish [Fig. 5.9].

Aeltgen (after 1610-1653), the youngest sister of Jacob and François Eelkens, entered the Ursuline convent in Évreux, a city in Normandy East of Rouen. As a nun under the name of Soeur Alix de Saint-Bernard Elequens she performed semi-public miracles, such as the miraculous multiplication of corn that would have been unthinkable in the cramped and complex confessional context of Holland. According to the chronicle of the convent, her devotion was styled by the Rouen Jesuits and she died in an aura of sanctity, just as her brother who was a priest in Brussels. ${ }^{27}$ Although the members of the Catholic Eelkens family had to cope with fundamentally different confessional contexts in Amsterdam and in Rouen or Évreux, this seems not to have been felt as a moral or private problem. Indeed, it was after the Alteration of Amsterdam that the Catholic fur trader Frans Eelkens (the elder) left his Catholic town of Bois-le-Duc to establish his trade in booming Reformed Amsterdam - by then a far better place as Amsterdam was the port of departure for merchant

25 Noordhollands Archief Haarlem, Notarial Archives, vol. 153, fols. 55v-6ov (notary Jacob Schoudt).

26 Frijhoff, "The Oratory in the Seventeenth-Century Low Countries" 196.

27 Cambounet de La Mothe Jeanne de, Journal des illustres religieuses de l'ordre de SainteUrsule, avec leurs maximes et pratiques spirituelles, vol. 3 (Bourg-en-Bresse, chez Ioseph Ravoux: 1686) 10-11. 


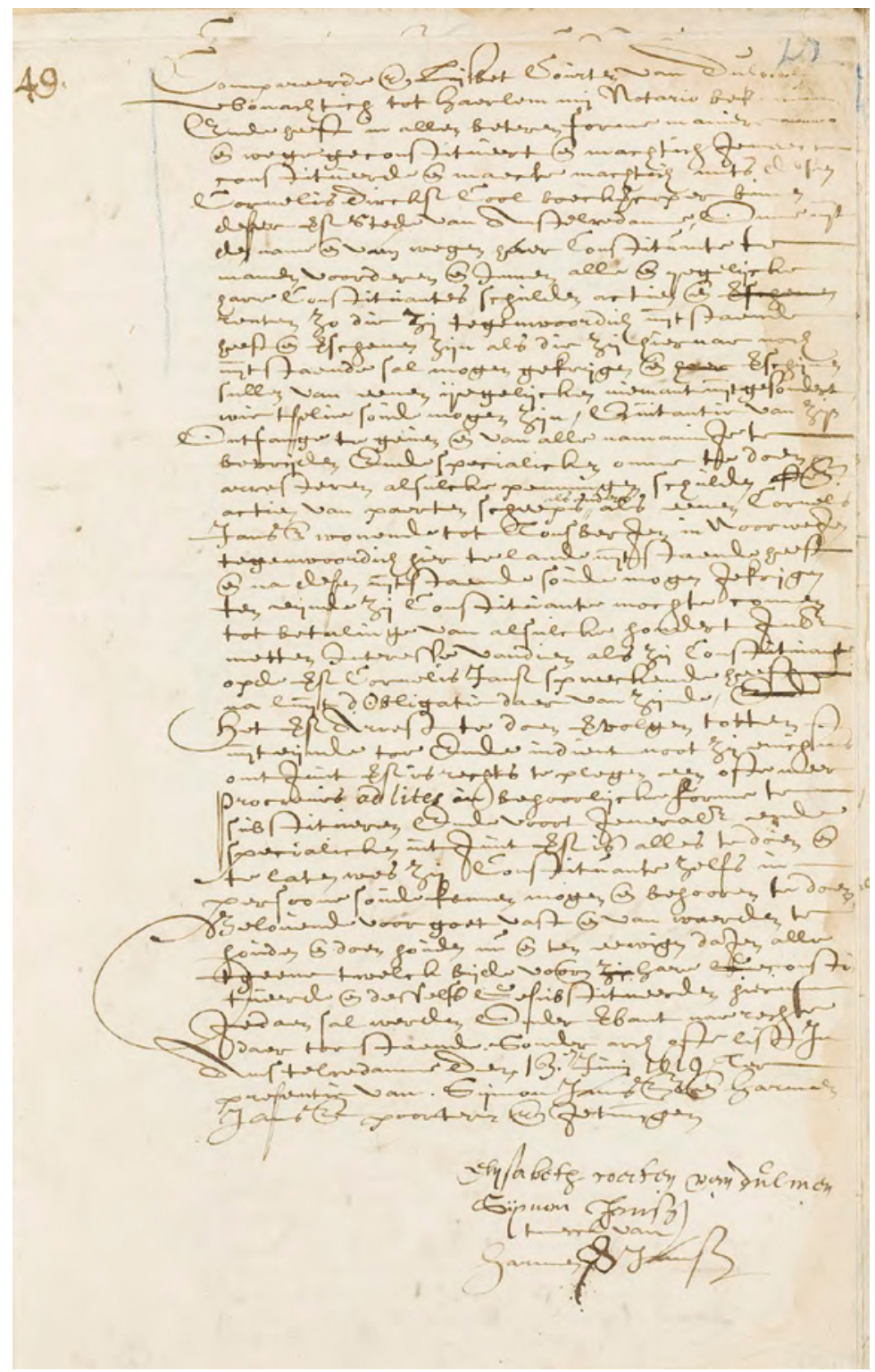

FIGURE 5.7 City Archives Amsterdam, Notarial Records, arch. numb. 5075, inv. numb. 59o, act numb. 196357, 13 June 1619. Procuration signed by Lysbeth Coerten van Dulmen, now living at Haarlem, to Cornelis Dircxs Cool, [Catholic] bookseller in Amsterdam, for the payment of all her debts, including her shares in ships pertaining to Cornelis Jans in Tønsberg (Norway) 


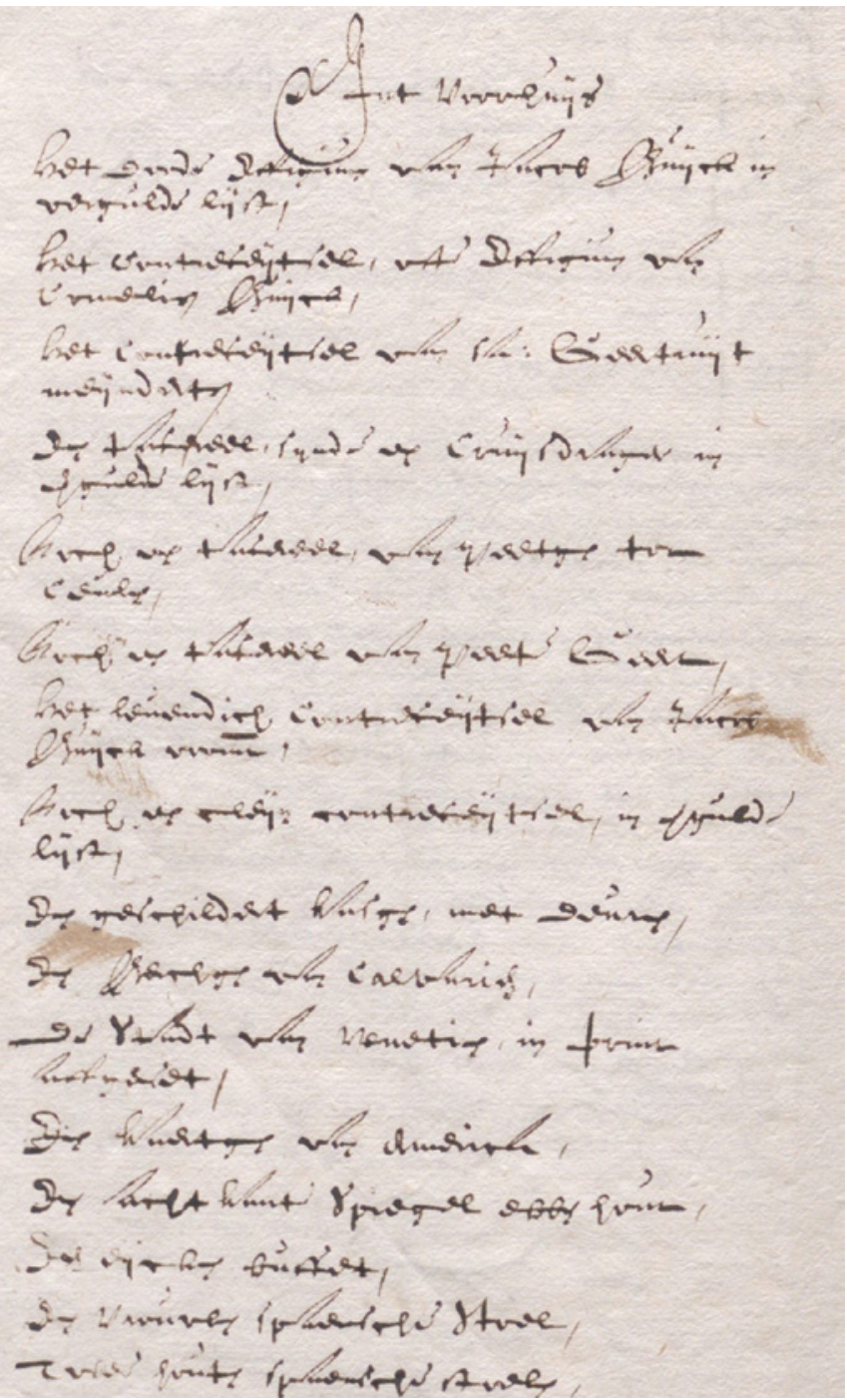

FIGURE 5.8 Noordhollands Archief, Notarieel archief Haarlem 153, f. $55 \mathrm{v}-6 \mathrm{ov}$ [notary Jacob Schoudt], here 55v. First page of the probate inventory of Lysbeth Coerten van Dulmen ( $\uparrow 1$ September 1640); drawn up by her executors, her nephew Hendrick Stockmans (a wholesale merchant) and Cornelis Dircxs Cool (bookseller). Among the $3^{1}$ paintings, except those of close family members, several typically Catholic subjects: a Holy Virgin (by Jan van Scorel), a Crucifix, a Christ bearing the Holy Cross, Mount Calvary, an Ecce Homo, the Samaritan Woman, the Four Evangelists, a painting of Jacob and Esau; and also a map of America, and a view of the city of Venice 
ro La. Saur alix de S. Bernard, Elequens. s. Juilliet.

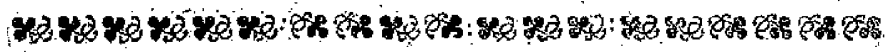

\author{
TROISIEME JHILET. \\ LA VENERABLE SOEUR ALIX DE \\ Saint Bernard, Flequens, Religieufe \\ Urfuline d'Evreux.
}

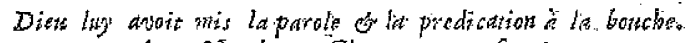
Aux Nombes, Chap. 2.3. verf. $3: 6$.

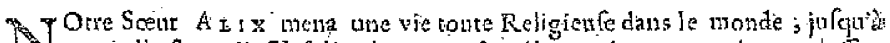

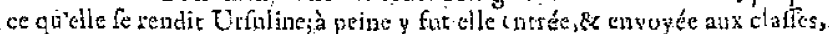

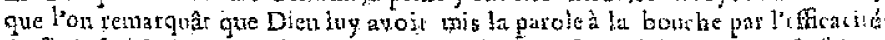

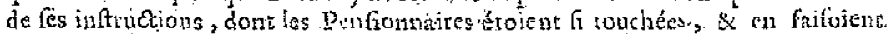
un fi grand recit que les atures filles pan devorion demantoient lentendre;

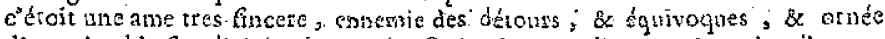

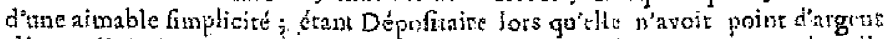

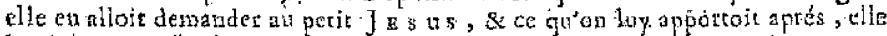

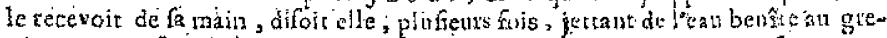
nier a \& y difane devotement le Credo le bled s'y muiriplioit o une fois enirea

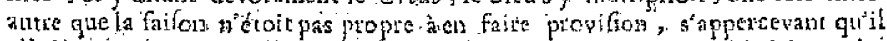

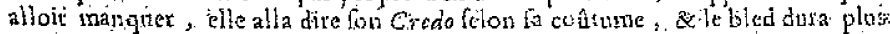

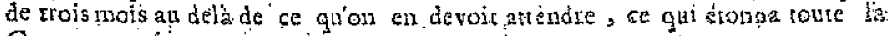
Communante.

Etle excelloir en la vertu d'obethance entre tontes les autres, birn gavelle fus

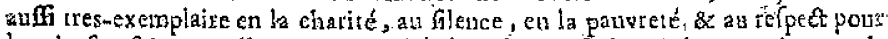
les chofes fainres, elle s'achemina da bien. heurenfe éternité par trois ans de

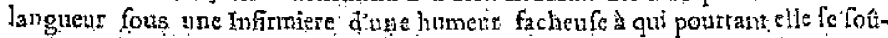
metroir entieremenc, elle reçeut le S.Viatique, \& tendir l'ame pendant qu'on

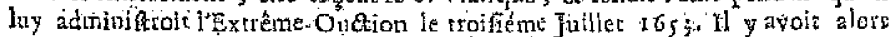
deux perfonnes fort à charge dars les Ujufulines, $2 x$ dont elles ne fe pouveient befaire, a canfe que des hautes puifinances les avointab obligés de les recevoir; nôtre Scenr de S. Bernatd dans fon extrémité pronail à fes Seenrs que la prestiere chofr gurelie demanderoit a Nôre Seigneur, silluy faifoit la grace de la thetre eir con Patadis, ee feroir la fordie de ces filles, \& dans la quinzaine apéés ton décez elles fortirent ề effer d'une maniere inefyerée tộ que la Corinumaté tinf àne grande grace de Dietr;
\end{abstract}

FIGURE 5.9 Journal des illustres religieuses de l'ordre de Sainte-Ursule, avec leurs maximes, pratiques spirituelles, vol. 3 (Bourg en Bresse, chez Ioseph Ravoux, Imprimeur \& Libraire: 1686) 10. 'The miracle of the corn multiplication repeatedly performed at the Ursuline convent of Evreux through the devout intercession of Sister Alix de Saint-Bernard [= Aeltgen Eelkens, Fw], by prayer, and aspersion of the convent's attic with holy water' 
ships that sailed towards the fur paradise of North America. This move meant, however, that henceforth the family's Catholic practice had to be restricted to the private domain.

At closer analysis we can detect in both situations, in Amsterdam and in Rouen, a double identity, private and social. The Catholics in Amsterdam formed essentially a Dutch ethnic and historical community, cherishing traditional public Dutch values, but they were limited in their expressions because they had to foster a clandestine Catholic identity. This identity was confessional, but it was also marked by personal, private choices and adaptations of the established group practices. This subaltern social position facilitated the development of a more private identity because the persons concerned could more easily withdraw from the public pattern of obligations and silently impose their own values and customs. On the other hand, the family members at Rouen could freely practise their Catholic faith but were limited in their social settings by their Dutch origin, culture, and nationality. In both cases, their private actions show the ardent desire to overcome these limitations. In Amsterdam, they contributed to the creation of a fully-fledged, alternative Catholic stratum of the population with its own internal hierarchy of positions and values, including a secret or clandestine organisation of their Catholic religious life. It was in many respects a parallel society that imitated the rituals and customs of the former, predominantly Catholic situation but reduced to the private sphere the essential marks of religious adhesion: not only baptism, marriage, and assistance at mass, but also education and reading culture. In Rouen, the family members participated as Catholics in the local merchant class, but at the same time they organised their personal life with much more regard to the important group of merchants of Dutch origin, mostly consisting of active Protestants who had to practise their faith in the temple of Quevilly outside the city. ${ }^{28}$ As early as the second generation, some members of Catholic immigrant families in Rouen invited Protestant Dutch merchants or their family members to be their baptismal witnesses, guardians of their orphans, or participants in other privileged private relations, and vice versa. Apparently, in their view, when it came to maintaining a group cohesion in which private life could also prosper, the merchant community, their origin, and their everyday private relations carried more weight than their religious identity.

28 Frijhoff W., "Entre l'Édit de Nantes et la Révocation: les négociants néerlandais à Rouen face aux divisions religieuses", Revue d'histoire du protestantisme 4 (2019) 281-309. 


\subsection{Privacy, Secrecy, Illegitimacy}

It is important to maintain in our research the distinction between privacy and the secrecy to which a clandestine pattern of behaviour or a forbidden group is bound. Privacy pertains to history from below; secrecy might as well pertain to high-level intelligence or political action. In early modern society, with its many religious enclosures, social prohibitions, and political interdictions, there were many reasons for secrecy that do not or only very partially cover the broad domain of privacy. Take, for instance, forbidden churches or religious groups; secret rituals such as clandestine marriages; mysticism, magic, and alchemy; actions of class solidarity against the powerful, and political conspiracy; prostitution, drugs, and organised fraud and crime. All these domains comprise some part of private action but derive their secrecy not from this private character but from the social organisation that has placed them beyond the law. That was the case for the clandestine churches in private houses. In his study of religious toleration, Benjamin Kaplan rightly calls them 'fictions of privacy'. ${ }^{29}$ Indeed, as centres of the religious practice of a privatised group in the civic community, they were invisible from the outside. Yet, everybody knew of their existence. It could be inferred from the semi-public, barely private stream of Catholic, Lutheran, Remonstrant or Anabaptist churchgoers in the streets on Sundays and holidays. In the cities where such 'house churches' were formally tolerated, their interior could be impressive as can still be seen in the former clandestine Catholic church called 'Our Lord in the Attic' near the Reformed Old Church of Amsterdam, in the Catholic chapel on the Beguinage, and in the huge Remonstrant Church built in 1629-1630 behind the house at Keizersgracht 102 under the sign 'Vrijburg' (now known as 'The Red Hat'). ${ }^{30}$

A case in point for the theme of privacy in a family context is the position of illegitimate children born out of wedlock. For different reasons they were numerous in former centuries: sexual urge, conventions of the youth culture, the 'lack' of women or spouses overseas, the absence of a clear marital ethos, or marriage problems, as we saw in the two cases of concubinage discussed above. Illegitimate children, a consequence of their parents' undue or unforeseen private initiative, had to suffer public dismay and they lacked legal rights, even if for the purposes of their education or work they could remain under their parents' care, included in their family on the same level as the legal

29 Kaplan B.J., "Fictions of Privacy: House Chapels and the Spatial Accommodation of Religious Dissent in Early Modern Europe", in Kaplan B.J., Reformation and the Practice of Toleration (Leiden - Boston: 2019) 164-203.

Boers Th. - Kiers J., Ons' Lieve Heer op Solder: Our Lord in the Attic (Amsterdam: 2015). 


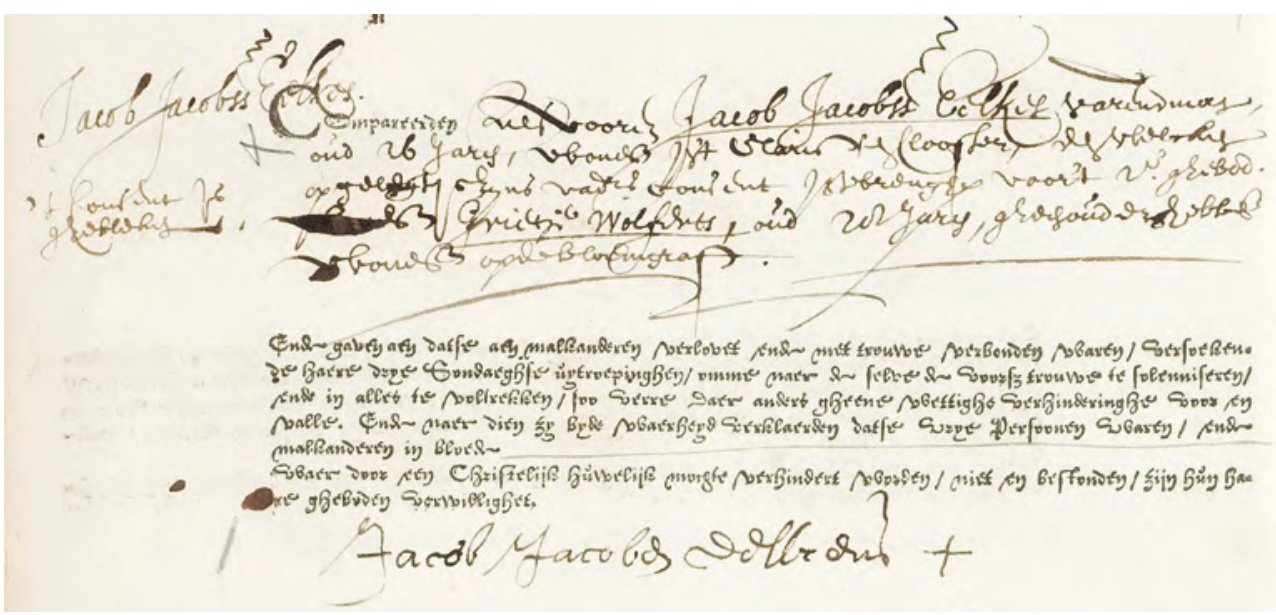

FIgURE 5.10 City Archives Amsterdam, Marriage Records, arch. numb. 5001, inv. numb. 668, f. $25^{8}$ (fragment). 'Civil marriage in the City Hall of Amsterdam 22 June 1619, of Jacob Jacobss Eelkens [26, wF], "seaman", living in former St. Clare's convent, and Grietje Wolferts [28, signs with a cross, WF], living on the Bloemgracht [both Catholics, WF]'

(C) CITY ARCHIVES AMSTERDAM

children. In the case of the ambitious Jacob Eelkens, I presume that his harsh break with his family was his personal answer to the many obstacles caused by his illegitimate status. It was overseas, and later in the service of other nations, that he could establish a public life unhampered by the prohibitions of his illegitimate origin. It is significant that, at the age of 26 , during a short stay in Amsterdam after long years of a relatively lonely sojourn in North America, he married a girl of much simpler origin, Grietgen Wolferts (159o/91-after 1619). She came from a lower-class neighbourhood of Amsterdam and she must have been uneducated seeing that she was unable to sign her name. Moreover, her father Wolfert Claess (ca. 1562-1605), a carpenter, had suffered a criminal conviction. On the other hand, all of Jacob's legal brothers and sisters, cousins and nephews made promising marriages involving successful merchants who belonged to the upper layers of the burgher society in Holland and France. The other exception to this general impression is another illegitimate child, Maritgen Eelkens (1622-1650), born out of an unknown but premarital relationship of Jacob's uncle Hendrick Eelkens, the shipowner and international merchant in whose service Jacob had been for some years. She was to remain a simple unmarried schoolmistress who died childless [Figs. 5.10-5.11]. 


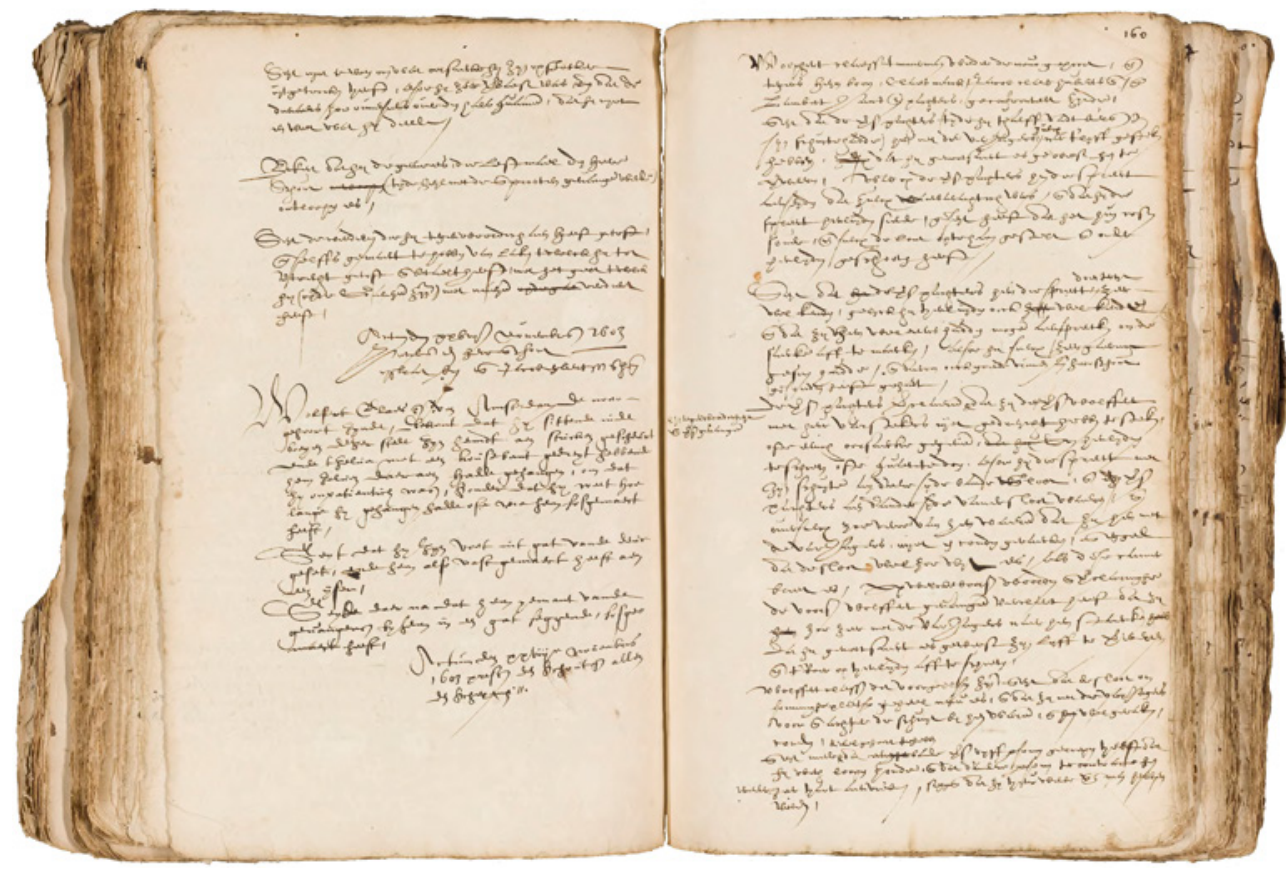

FIGURE 5.11 City Archives Amsterdam, Criminal records of Amsterdam, 2o November to 2 December 1603, arch. numb. 5061, inv. numb. 282-16o2 f. 159r-16ov. The text tells that Wolfert Claess, house carpenter in Amsterdam [father of Grietgen Wolferts, father-in-law of Jacob Eelkens], is sentenced for issuing death threats to the five collectors of the beer tax who had threatened him. He is imprisoned. Once in prison and desperate, he tried to hang himself, but he was saved in time by a co-prisoner in his cell (summary of the text). (C) CITY ARCHIVES AMSTERDAM

Looking for the private dimension in such a family network implies three fields of observation: experience, emotion, and memory. That is to say, it implies the way people acted, the way they thought, felt motivated, and made decisions, and the way they remembered their life and their past. For the early modern period their private agency must mainly rely on my analysis of other sources related to their actions and experiences as family members, merchants, or Catholics (level II). When close reading the available textual sources, one has to keep in mind that all forms of such reconstruction of meanings need the check of a sound theoretical reflection and of methodical caution. There is no lack of such sources. However, they are not always significant in themselves but derive 
their meaning as historical sources above all from their contextualisation - a complex and multi-layered procedure that is the professional secret of the experienced historian. In my case that means the reconstruction, as completely as possible, of a number of families as a kinship network whose members acted privately or together in the service of commercial, social, and religious needs.

\section{Bibliography}

Baillet Adrien, Vie de M. Descartes, 2 vols. (Paris: 2012 [Paris, chez Daniel Horthemels: 1691]).

Boers Th. - Kiers J., Ons' Lieve Heer op Solder: Our Lord in the Attic (Amsterdam: 2015).

Cambounet de La Mothe Jeanne de, Journal des illustres religieuses de l'ordre de Sainte-Ursule, avec leurs maximes et pratiques spirituelles, vol. 3 (Bourg-en-Bresse, chez Ioseph Ravoux: 1686).

Farin François, Histoire de la ville de Rouen, 3rd ed. (Rouen, chez Louis du Souillet: 1731). Frijhoff W., "The Improbable Biography: Uncommon Sources, a Moving Identity, a Plural Story?", in Berghahn V.R. - Lässig S. (eds.), Biography between Structure and Agency: Central European Lives in International Historiography (Oxford - New York: 2008) 215-233.

Frijhoff W. - Prak M. (eds.), Geschiedenis van Amsterdam, vol. 2-1: Centrum van de wereld 1578-1650, 2nd ed. (Amsterdam: 2009 [2004]).

Frijhoff W., "La coexistence confessionnelle dans les Provinces-Unies: un régime de connivence à plusieurs vitesses", in Dumont M. (ed.), Coexistences confessionnelles en Europe à l'époque moderne. Théories et pratiques, $X V I^{e}-X V I I^{e}$ siècles (Paris: 2016) $105^{-124 .}$

Frijhoff W., "Dimensions de la coexistence confessionnelle", in Berkvens-Stevelinck C. - Israel J. - Posthumus Meyjes G.H.M. (eds), The Emergence of Tolerance in the Dutch Republic (Leiden - New York - Cologne: 1997) 213-237.

Frijhoff W., "A Misunderstood Calvinist: The Religious Choices of Bastiaen Jansz Krol, New Netherland's First Church Servant", Journal of Early American History 1.1 (2011) $62-95$.

Frijhoff W., "Experience and Agency at the Crossroads of Culture, Mentality, and Contextualization. The Biography of Everhardus Bogardus (c. 1607-1647)", in Bödeker H.E. (ed.), Biographie schreiben (Göttingen: 2003) 65-105.

Frijhoff W., "La tolérance sans édit: la situation dans les Provinces-Unies", in Delumeau J. (ed.), L'Acceptation de l'autre de l'Édit de Nantes à nos jours (Paris: 200o).

Frijhoff W., "Religious Toleration in the United Provinces. From 'Case' to 'Model", in Po-Chia-Hsia R. - Nierop H. van (eds.), Calvinism and Religious Toleration in the Dutch Golden Age (Cambridge: 2002). 
Frijhoff W., "Seitenwege der Autonomie. Wege und Formen der Erziehung in der Frühen Neuzeit", in Jacobi J. - Le Cam J.L. - Musolff H.U. (eds.), Vormoderne Bildungsgänge. Selbst- und Fremdbeschreibungen in der Frühen Neuzeit (Cologne Weimar - Vienna: 2010) 25-42.

Frijhoff W., "The Oratory in the Seventeenth-Century Low Countries", Revue d'histoire ecclésiastique 107.1 (2012) 166-222.

Frijhoff W., Embodied Belief. Ten Essays on Religious Culture in Dutch History (Hilversum: 2002).

Frijhoff W., Wegen van Evert Willemsz. Een Hollands weeskind op zoek naar zichzelf, 1607-1647 (Nijmegen: 1995).

Frijhoff W., Fulfilling God's Mission: The Two Worlds of Dominie Everardus Bogardus 1607-1647 (Leiden - Boston: 2007). English version of the above.

Frijhoff W., "Michel de Certeau (1925-1986)", in Daileader Ph. - Whalen Ph. (eds.), French Historians 1900-2000. The New Historical Writing in Twentieth-Century France (Chichester UK: 2010) 77-92.

Frijhoff W., "Entre l'Édit de Nantes et la Révocation: les négociants néerlandais à Rouen face aux divisions religieuses", Revue d'histoire du protestantisme 4 (2019) 281-309.

Frijhoff W., "Jacob Eelkens Revisited: A Young Franco-Dutch Entrepreneur in the New World", De Halve Maen. Magazine of the Dutch Colonial Period in America 88.1 (2015) $3^{-12 .}$

Hell M., De Amsterdamse herberg 1450-1800. Geestrijk centrum van het openbare leven (Nijmegen: 2017).

Heussen Hugo Franciscus van, Historia Episcopatuum Foederati Belgii, 6 vols. (Leiden, Christiaan Vermey: 1719).

Heuvel Ch. van den, 'De Huysbou': A Reconstruction of an Unfinished Treatise on Architecture, Town Planning and Civil Engineering by Simon Stevin (Amsterdam: 2005).

Kaplan B.J., "Fictions of Privacy: House Chapels and the Spatial Accommodation of Religious Dissent in Early Modern Europe", in Kaplan B.J., Reformation and the Practice of Toleration (Leiden - Boston: 2019) 164-203.

Molhuysen P.C., Geschiedenis der Universiteits-Bibliotheek te Leiden (Leiden: 1905).

O'Callaghan E.B., Documents Relative to the Colonial History of the State of New York, vol. 1 (Albany: 1853).

Richter D.K., "Rediscovered Links in the Covenant Chain: Previously Unpublished Transcripts of New York Indian Treaty Minutes, 1677-1691", Proceedings of the American Antiquarian Society 92.1 (1982) 45-85.

[Swert Pierre de], Chronicon Congregationis Oratorii Domini Jesu per Provinciam ArchiEpiscopatus Mechliniensis diffusae (Whitefish, MT: 2010 [Lille, Petrus Matthon: 1740]). 
Vries David Pietersz de, Korte Historiael ende Journaels aenteyckeninge van verscheyden Voyagiens in de vier deelen des Wereldts-Ronde, 4 vols. (Hoorn, voor D.P. de Vries: 1655), ed. H.T. Colenbrander (The Hague: 1911).

Wassenaer Nicolaes van, Historisch verhael alder ghedenck-weerdichste geschiedenisse, die hier en van den beginne des jaers 1621 [tot Octobri des jaers 1632] voorgevallen syn, vol. 4 (Amsterdam: 1626) November 1626.

Winthrop John, A Journal of the Transactions and Occurrences in the Settlement of Massachusetts from the year 1630 to 1644 (Hartford, Elisha Babcock: 1790). 